Vol. 7 No.1 Tahun 2021, pp. 20-28
Jurnal Teknologi dan Manajemen Informatika
http:// http://jurnal.unmer.ac.id/index.php/jtmi
P-ISSN: $1693-6604 \quad$ E-ISSN: 2580-8044

\title{
Sistem Informasi Manajemen Data Pengadaan Barang atau Jasa (SiMDA-PBJ) Berbasis Web
}

\author{
Farid Wahyudi ${ }^{1}$, Listanto Tri Utomo ${ }^{2}$ \\ 1,2 Program Studi Sistem Informasi, Fakultas Sains dan Teknologi, Universitas Islam Raden Rahmat \\ Malang
}

Info Artikel

Riwayat Artikel

Diterima: 14-06-2021

Direvisi: 25-06-2021

Disetujui: 05-07-2021

Kata Kunci

Sistem Informasi

Manajemen;

Pengadaan Barang atau Jasa;

Web;

Corresponding Author

Farid Wahyudi,

Universitas Islam Raden

Rahmat Malang,

Tel. +62 85755817853

Email:

faridstifler@gmail.com

\begin{abstract}
ABSTRAK
Kemudahan akses informasi dan fleksibilitas penginputan data terkait pengadaan barang atau jasa pemerintah sangat diperlukan tidak hanya bagi masyarakat umum guna keterbukaan data dan transparansi, namun juga bagi perangkat daerah yang memiliki tugas dan fungsi dalam bidang pengadaan barang atau jasa sebagai tolok ukur peningkatan kinerja. Analisis dan perancangan sebuah sistem informasi yang dapat melakukan manajemen data terhadap paket pekerjaan pengadaan barang atau jasa dirasa mampu menjadi solusi terhadap kebutuhan tersebut. Penelitian ini dilaksanakan pada Bagian Pengadaan Barang atau Jasa Sekretariat Daerah Kabupaten Malang. Tujuan dari penelitian ini adalah menghasilkan aplikasi berbasis web sebagai sarana pendukung/pelengkap sistem pengadaan secara elektronik dari Lembaga Kebijakan Pengadaan Barang atau Jasa Pemerintah (LKPP) dalam bidang penyajian data informasi guna memudahkan masyarakat apabila ingin mengetahui data pengadaan barang atau jasa pada Pemerintah Kabupaten Malang, serta sebagai sarana pendukung peningkatan kinerja perangkat daerah terkait pelaporan data terhadap pejabat eksekutif. Hasil penelitian menunjukan dengan penggunaan model perancangan system development life cycle (SDLC) metode waterfall mampu membuat aplikasi SiMDA-PBJ yang dapat menunjang kebutuhan terkait penyajian informasi dan penyusunan laporan pengadaan barang atau jasa Pemerintah Kabupaten Malang secara cepat dan real-time. Dapat diambil kesimpulan bahwa aplikasi SiMDA-PBJ berbasis web mampu memenuhi penyajian data yang mendukung azas keterbukaan informasi dan transparansi serta memudahkan aparatur dalam penginputan data bidang pengadaan barang atau jasa pemerintah.
\end{abstract}

\section{PENDAHULUAN}

Kebutuhan keterbukaan data dan informasi sebagai bentuk transparansi pada paket pekerjaan pengadaan barang atau jasa pemerintah yang dapat diakses dengan mudah oleh masyarakat sekaligus menciptakan fleksibilitas dalam pengelolaan data untuk aparatur yang memiliki tugas fungsi dalam pengadaan barang atau jasa, dirasa perlu dilakukan pemecahan masalah dan solusinya. Penggunaan sistem informasi manajemen data berbasis web merupakan salah satu bentuk upaya yang dapat dilakukan guna pemenuhan kebutuhan tersebut. Sistem informasi berbasis web disamping dapat memberikan informasi dan data secara real-time yang dapat diakses di manapun dan kapanpun, tetapi juga mampu meningkatkan kinerja sebuah perangkat daerah dalam hal ini bagian Pengadaan Barang atau Jasa Sekretariat Daerah Kabupaten Malang dalam pemenuhan sasaran kegiatan dan penyampaian laporan kepada pejabat eksekutif diatasnya. 
Sebagai upaya membangun latar belakang pelaksanaan penelitian ini, penulis mencari referensi dan literatur dari beberapa jurnal sejenis yang terkait dengan sistem informasi pengadaan barang atau jasa dan dari beberapa jurnal tersebut dipilih jurnal dengan judul "Analisis dan Perancangan Sistem Informasi Layanan Pengadaan Barang dan Jasa Berbasis Web Pada Polda Jambi" yang ditulis oleh Marlinda Tina dan Joni Devitra - STIKOM Dinamika Bangsa Jambi. Isi dari jurnal tersebut menghasilkan tentang aplikasi pengadaan barang dan jasa yang dapat diakses secara lokal dilingkungan kantor polda jambi[10]. Merujuk penelitian terdahulu sebatas bisa diakses secara lokal, maka pada aplikasi sistem informasi pengadaan barang dan jasa yang dikembangkan peneliti dapat diakses secara realtime dan dimanapun asalkan ada akses internet.

Melihat latar belakang diatas, penelitian ini bertujuan untuk menghasilkan aplikasi berbasis web sebagai sarana pendukung atau pelengkap sistem pengadaan secara elektronik dari Lembaga Kebijakan Pengadaan Barang atau Jasa Pemerintah (LKPP) dalam bidang penyajian data informasi guna memudahkan masyarakat apabila ingin mengetahui data pengadaan barang atau jasa pada Pemerintah Kabupaten Malang, serta sebagai sarana pendukung peningkatan kinerja perangkat daerah terkait pelaporan data terhadap pejabat eksekutif. Batasan masalah penelitian ini hanya sampai tahap analisis perancangan sistem dan ujicoba aplikasi sistem informasi manajemen data pengadaan barang atau jasa (SiMDA-PBJ) terhadap user atau aparatur pada Bagian Pengadaan Barang atau Jasa Sekretariat Daerah Kabupaten Malang.

\section{METODE}

\section{Metode Pengumpulan Data}

Data yang dikumpulkan bermaksud untuk mendapatkan sebuah informasi yang berasal dari data - data yang diperoleh secara detail, benar dan lengkap untuk digunakan dalam melakukan perancangan dan analisis sistem yang akan di rancang.

a. Observasi

Tujuan dari observasi adalah dengan mendeskripsikan setting yang diamati, tempat kegiatan orang - orang yang berpartisipasi dalam kegiatan tersebut dan makna apa yang diamati menurut prespektif penulis. Pada pengamatan berperan serta, penulis melakukan dua peran sekaligus, yaitu sebagai pengamat dan sekaligus menjadi anggota penelitian dari kelompok penelitian. Pengumpulan data meliputi data paket pekerjaan pengadaan barang atau jasa pemerintah kabupaten malang tahun 2020 pada Bagian Pengadaan Barang atau Jasa Sekretariat Daerah Kabupaten Malang.

b. Wawancara

Wawancara merupakan percakapan dengan maksud tertentu. Percakapan dilakukan antara penulis yang mengajukan pertanyaan dan yang diwawancarai memberikan jawaban atas pertanyaan itu. Proses wawancara ini dilakukan untuk mendapatkan masukan dari pengguna/user dengan tujuan untuk mengetahui sistem seperti apa yang dibutuhkan oleh Bagian Pengadaan Barang atau Jasa Sekretariat Daerah Kabupaten Malang dari segi arsitektur aplikasi, teknologi yang digunakan serta pemanfaatannya.

2. Metode Pengembangan Perangkat Lunak

System Development Life Cycle (SDLC) model waterfall adalah yang penulis gunakan dalam analisis dan perancangan pengembangan aplikasi SiMDA-PBJ. Waterfall Model atau Classic Life Cycle merupakan model yang paling banya dipakai dalam Software Enginnering (SE) karena tahap demi tahap yang harus dilalui menunggu selesainya tahap sebelumnya dan berjalan berurutan [2]. pola yang diambil untuk mengembangkan sistem perangkat lunak, yang terdiri dari tahap - tahap yaitu rencana (planning), analisis (analysis), desain (design), implementasi (implementation), uji coba (testing) dan pengelolaan (maintenance). 


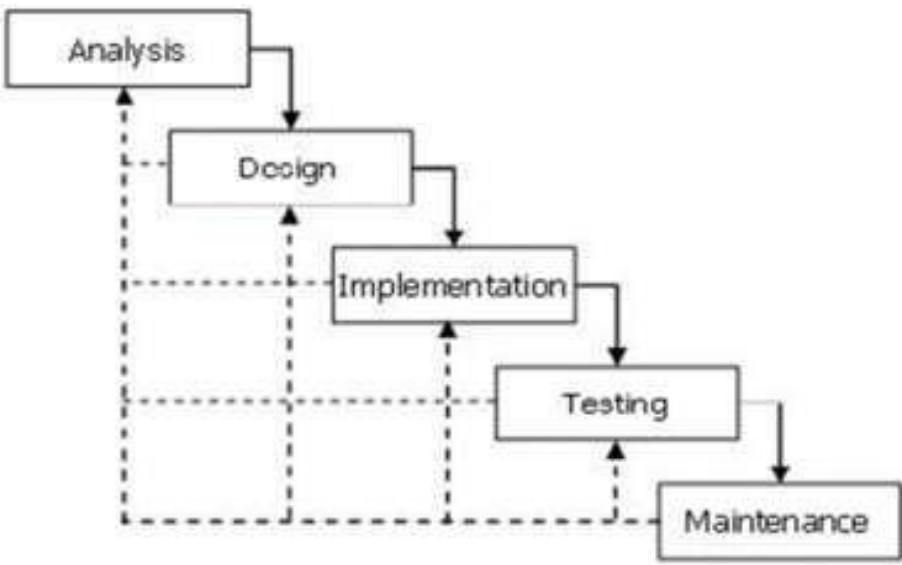

Gambar 1. Metode Waterfall

Tahap pertama kali dilakukan dengan cara mengumpulkan kebutuhan secara lengkap bertujuan dilakukan analisis. Kebutuhan yang akan dipenuhi oleh perangkat lunak yang akan dibangun, kemudian desain untuk memanifestasikan sebuah mekanisme dan menentukan alur perangkat lunak. Algoritma yang detail dilanjutkan dengan implementasi tahapan dimana yang nanti pada akhirnya sebuah desain diterapkan pada kode kode program, integrasi dan pengetesan. Tahapan ini dilakukan gabungan antara modul yang telah dirancang nantinya akan dilakukan sebuah pengetesan.

\section{HASIL DAN PEMBAHASAN}

\section{Analisis Kebutuhan Sistem}

Dari proses wawancara dan observasi dengan user, penulis dapat menarik beberapa kesimpulan dari keinginan user untuk aplikasi SiMDA-PBJ ini, diantaranya adalah :

a. SiMDA-PBJ bertujuan untuk menampilkan data paket pekerjaan pengadaan barang atau jasa Pemerintah Kabupaten Malang kepada masyarakat agar mengetahui pekerjaan apa saja yang telah dilakukan proses tender atau seleksi untuk selanjutnya ditindaklanjuti dengan pelaksanaan pekerjaan di lapangan;

b. SiMDA-PBJ memuat tentang informasi penyedia barang atau jasa yang telah menjadi pemenang dari paket pekerjaan pengadaan barang atau jasa, untuk dicatat dan diinventarisir mengenai informasi paket pekerjaan apa saja yang dimenangkan dan jumlah paket yang dilaksanakan guna memudahkan monitoring dalam pelaksanaan pekerjaan;

c. SiMDA-PBJ tidak hanya ditujukan untuk memberikan informasi kepada masyarakat, tetapi juga kepada level pimpinan dalam hal ini pejabat eksekutif sebagai upaya pelaporan kinerja yang telah dicapai oleh Bagian Pengadaan Barang atau jasa dalam melaksanakan tugas dan fungsinya

2. Perancangan Desain Sistem

Pada tahapan perancangan desain sistem ini penulis membuat beberapa metode permodelan untuk perancangan desain sistem yakni berupa Data Flow Diagram (DFD) dan Use Case Diagram, sedangkan untuk perancangan database menggunakan Entity Relationship Diagram (ERD). Data Flow Diagram merupakan alat yang populer, karena dapat menggambarkan arus data yang ada didalam sebuah sistem dengan terstruktur rapi dan jelas.

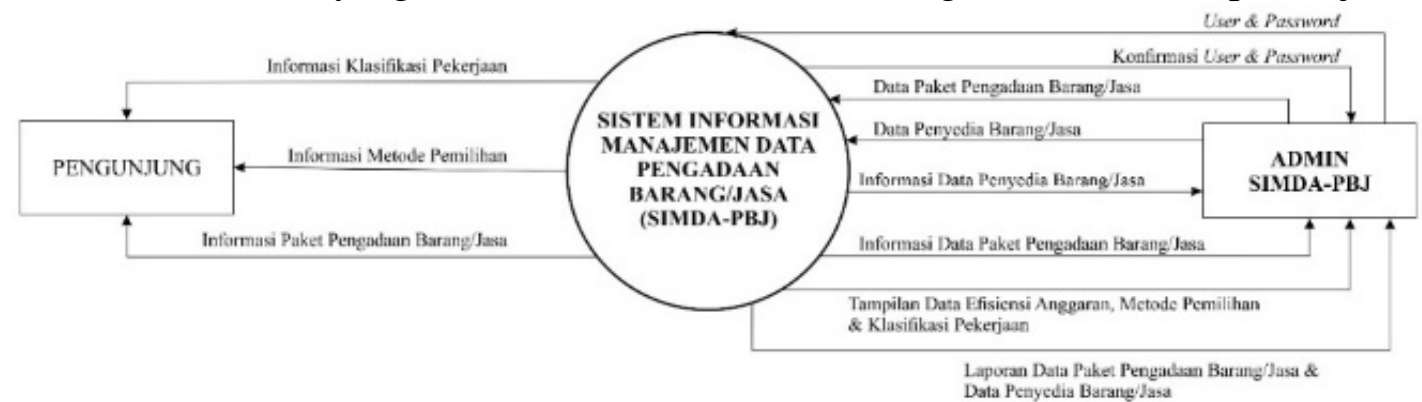

Gambar 2. Diagram Konteks/DFD Level 0 
Pada diagram konteks/data flow diagram level 0 sesuai dengan gambar terdapat aktivitas dari Admin SiMDA-PBJ dan Pengunjung. Aktivitas yang dilakukan oleh Admin SiMDAPBJ adalah mengelola data paket pekerjaan pengadaan barang atau jasa dan juga data penyedia barang atau jasa untuk selanjutnya diolah oleh sistem sehingga dapat memberikan laporan terkait data yang diminta. Sedangkan untuk Pengunjung akan mendapatkan informasi/data terkait pengadaan barang atau jasa dari aplikasi dari hasil hasil pengelolaan data yang di-input oleh Admin SiMDA-PBJ.

Selanjutnya setelah diagram konteks/data flow diagram level 0 selesai dibuat, tahapan selanjutnya adalah pembuatan data flow diagram level 1 dimana merupakan hasil terjemahan yang memperlihatkan detail dari alur proses yang digambarkan pada diagram konteks/data flow diagram level 0. Data flow diagram level 1 juga menampilkan secara garis besar tentang alur proses, pengiriman data dan jenis - jenis modul yang digunakan untuk mengolah sebuah informasi dari sebuah sistem. Dengan penggunaan data flow diagram level 1 setiap proses yang akan dilakukan oleh user dijelaskan secara lebih terstruktur berdasarkan modul/fungsi yang digunakan dalam sebuah sistem informasi yang akan dibangun.

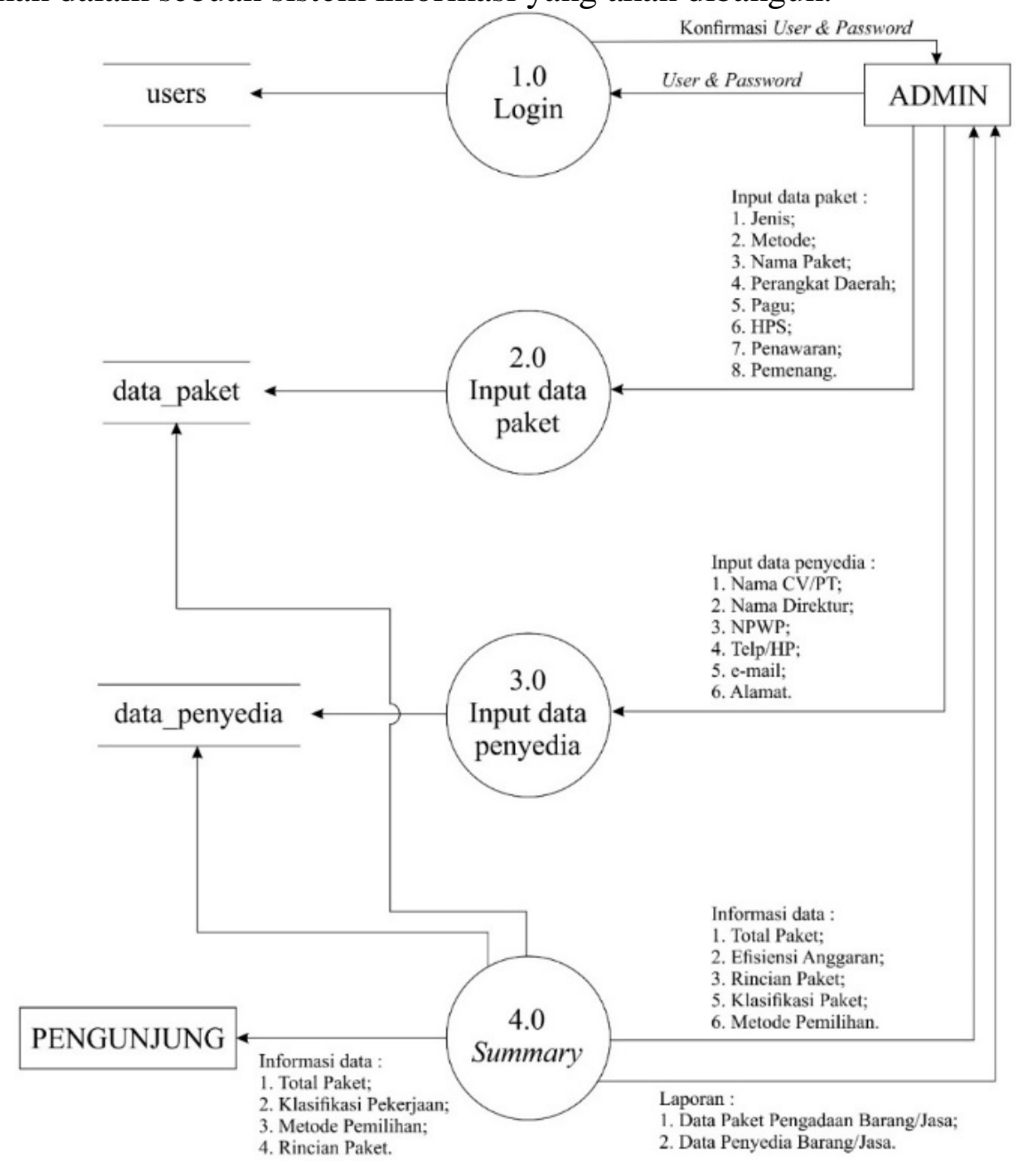

Gambar 3. Data Flow Diagram Level 1

Pada data flow diagram level 1 dijelaskan bahwa dalam aplikasi SiMDA-PBJ ini memiliki 4 proses yaitu login, input data paket, input data penyedia dan summary. Pada saat admin telah berhasil melakukan login kedalam aplikasi, langkah selanjutnya adalah melakukan input data paket dan data penyedia dimana keduanya saling berelasi, dimana hasil dari input data tersebut yang kemudian diproses atau diolah oleh aplikasi sehingga dapat menghasilkan laporan yang dapat dibaca dan dilihat baik oleh admin maupun pengunjung aplikasi.

Bagian selanjutnya dalam tahapan ini adalah pembuatan use case diagram yang menjelasakan tentang langkah - langkah dan juga skenario yang akan dilakukan oleh admin 
maupun pengunjung pada saat menggunakan aplikasi SiMDA-PBJ. Use case diagram juga digunakan untuk memprediksi kemungkinan - kemungkinan yang terjadi pada saat penggunaan aplikasi dimana prediksi tersebut nantinya akan diakomodasi pada tahapan implementasi pembuatan program aplikasi. Didalam use case diagram dijelaskan secara terstruktur fungsi - fungsi yang dilakukan oleh user yang nantinya setiap fungsi tersebut akan di definisikan skenarionya.

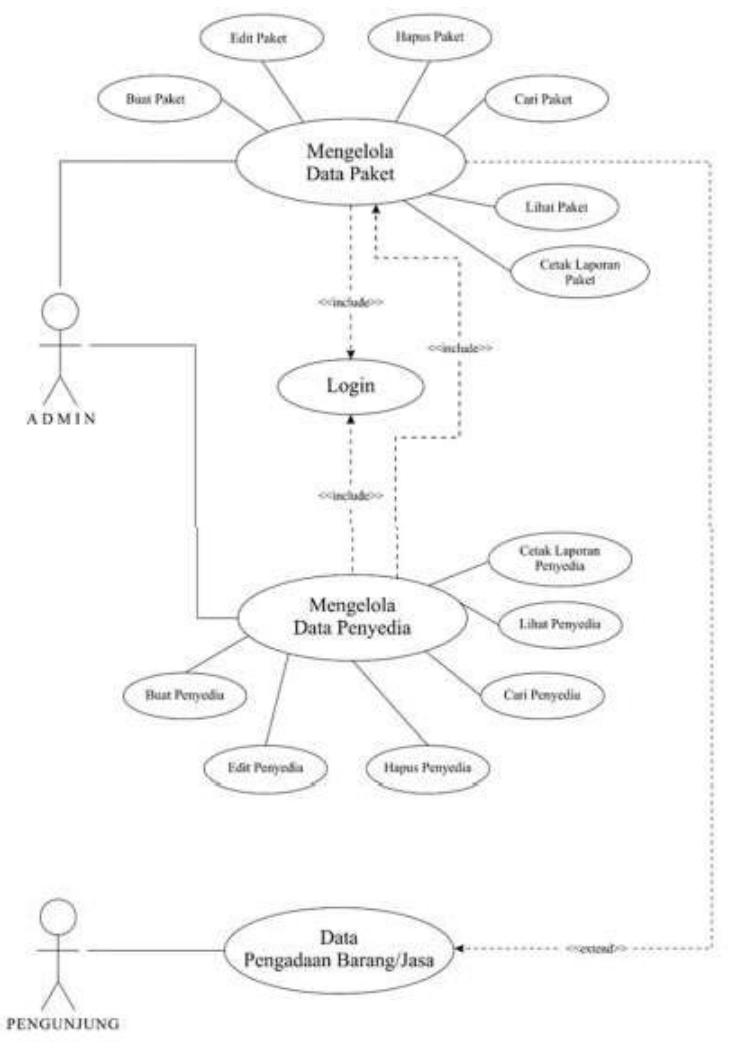

Gambar 4. Use Case Diagram SiMDA-PBJ

Pada use case diagram diatas dapat dilihat beberapa fungsi yang melibatkan user yaitu admin SiMDA-PBJ melakukan login kedalam aplikasi, mengelola data paket diantaranya buat paket, edit paket, hapus paket, cari paket, lihat paket dan cetak laporan paket. Disamping mengelola data paket admin SiMDA-PBJ juga melakukan pengelolaan data penyedia diantaranya buat penyedia, edit penyedia, hapus penyedia, cari penyedia, lihat penyedia dan cetak laporan penyedia. Fungsi data pengadaan barang atau jasa pada user pengunjung merupakan informasi data hasil pengelolaan data admin SiMDA-PBJ yang dapat dilihat dan diakses oleh siapa saja yang mengunjungi aplikasi SiMDA-PBJ.

Setelah dilakukan perancangan sistem dengan permodelan data flow diagram serta use case diagram, selanjutnya dilakukan perancangan database yang bertujuan untuk menggambarkan hubungan antar entitas. Database merupakan kumpulan file - file dalam sebuah tabel yang saling berkaitan. Pada model data relational hubungan antara file atau tabel direlasikan dengan kunci relasi (relation key), yang merupakan kunci utama dari masing masing file atau tabel. Dalam perancangan database ini penulis menerapkan permodelan entity relations diagram (ERD), dimana dengan permodelan tersebut dapat memberikan gambaran yang jelas tentang hubungan yang terjadi antar sesama entitas dalam sebuah tabel di dalam database. 


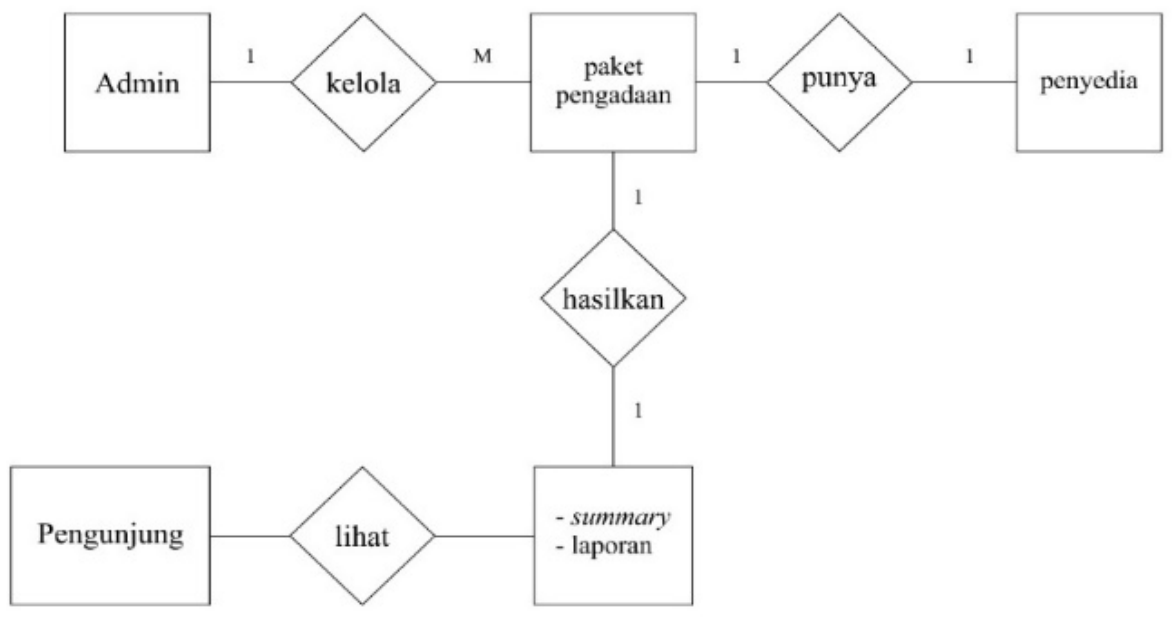

Gambar 5. Entity Relations Diagram SiMDA-PBJ

Entity Relations Diagram diatas menggambarkan entitas yang saling berhubungan dalam suatu database yaitu admin mengelola paket pengadaan dan penyedia barang atau jasa dimana data yang diolah tersebut memiliki relasi tabel, yang nantinya oleh aplikasi SiMDAPBJ sehingga dapat menyajikan informasi terkait pengadaan barang atau jasa di Kabupaten Malang yang dapat dilihat oleh pengunjung maupun admin.

Tahapan terakhir dalam perancangan deasin adalah perancangan antar muka/user interface. Dalam perancangan antar muka aplikasi sistem informasi manajemen data pengadaan barang atau jasa (SiMDA-PBJ) berbasis web ini dibuat beberapa halaman antar muka/user interface yang nantinya ditampilkan pada browser.

3. Implementasi Pemrograman Aplikasi

Pada tahapan/fase ini penulis melakukan proses coding pembuatan aplikasi sesuai dengan rancangan - rancangan pada tahapan sebelumnya dengan menggunakan bahasa pemrograman PHP dan Javascript. Proses coding ini dilakukan penulis untuk menerjemahkan hasil dari perancangan desain dengan harapan sesuai dengan permintaan dari user [9]. Untuk melakukan proses coding pada aplikasi ini, penulis menggunakan framework Laravel versi 7.0 dengan pertimbangan kemudahan dalam pengelolaan struktur pemrograman baik dari sisi back-end maupun front-end, Laravel memiliki beberapa fitur yang sangat membantu dalam pembuatan aplikasi diantaranya Eloquent ORM, Blade Templating dan Auth Middleware dimana fitur - fitur tersebut merupakan bagian yang sering digunakan dan diimplementasikan untuk membuat sebuah aplikasi berbasis web [1][3]. Sedangkan untuk desain user interface/antar muka menggunakan package CSS Bootstrap versi 4.0 guna memberikan tampilan yang baik dan easy to use.

Dari hasil implementasi pemrograman yang dilakukan penulis untuk aplikasi sistem informasi manajemen data pengadaan barang atau jasa (SiMDA-PBJ) telah berhasil didapatkan beberapa modul/fungsi sesuai analisis dan perancangan desain sehingga diharapkan dapat memudahkan penggunaan dan sesuai permintaan dari user, berikut merupakan hasil screenshot dari tampilan antar muka yang mengacu terhadap desain perancangan antar muka pada tahapan sebelumnya. 


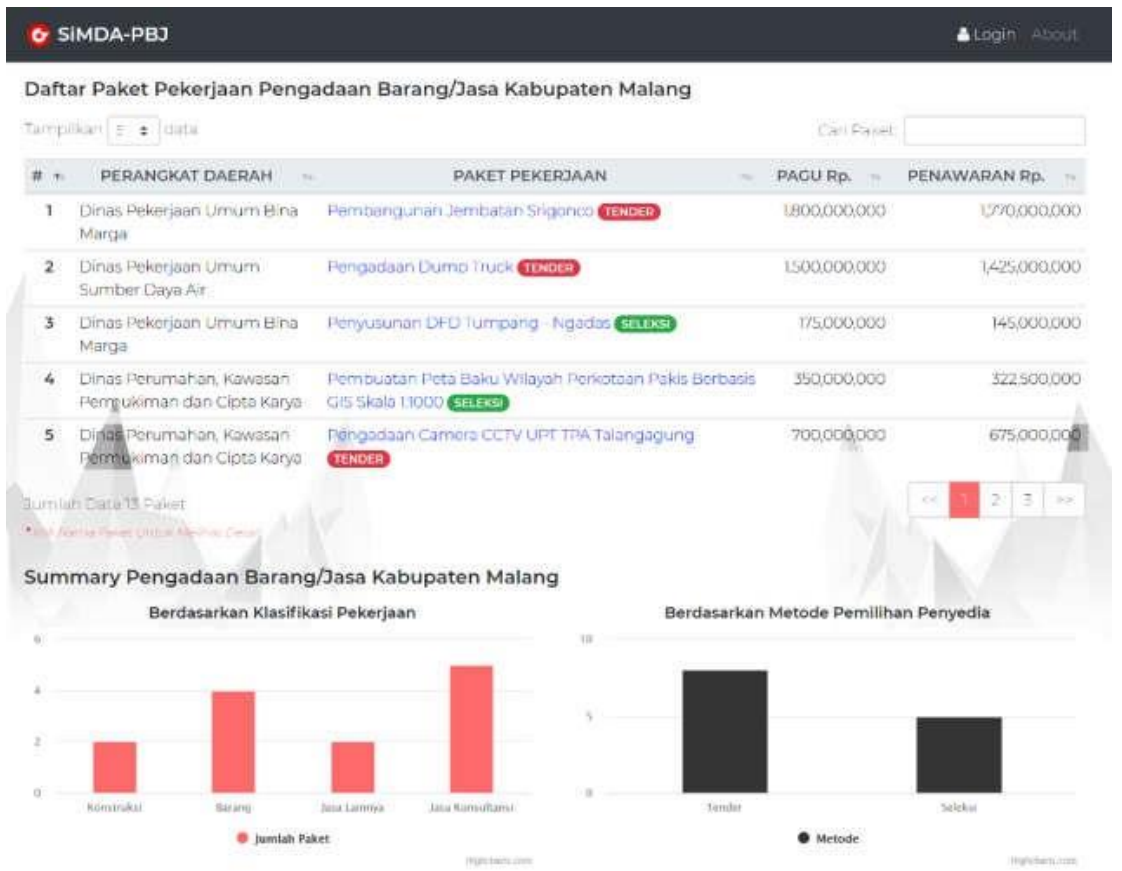

Gambar 6. Halaman Utama

Gambar 6 merupakan tampilan halaman utama pada aplikasi SiMDA-PBJ yang bertujuan untuk memberikan informasi dan data pengadaan barang atau jasa Pemerintah Kabupaten Malang kepada masyarakat atau pengunjung aplikasi. Data yang ditampilkan adalah paket pekerjaan pengadaan barang atau jasa berikut penyedia barang atau jasa dan grafik chart terkait metode pemilihan dan klasifikasi pekerjaan.

\section{Uji Coba Aplikasi}

Pengujian yang dilakukan terhadap aplikasi SiMDA-PBJ ini adalah pengujian dengan metode blackbox. Proses pengujian aplikasi dengan menggunakan metode blackbox ini dilakukan dengan menjalankan semua fungsi dan fitur yang ada dari aplikasi untuk kemudian dilihat apakah hasil dari fungsi - fungsi tersebut sesuai dengan yang diharapkan. Aplikasi ini dijalankan oleh user pada suatu web browser untuk kemudian mencoba mengakses aplikasi SiMDA-PBJ yang telah dilakukan konfigurasi sebelumnya dengan XAMPP dengan koneksi kedalam web server localhost. Berikut hasil dari pengujian terhadap aplikasi SiMDA-PBJ dapat dilihat pada tabel berikut ini:

Tabel 1. Hasil Pengujian Aplikasi SiMDA-PBJ Menggunakan Metode Blackbox

\begin{tabular}{|c|c|c|c|}
\hline Test Case & $\begin{array}{c}\text { Prosedur yang } \\
\text { dijalankan }\end{array}$ & $\begin{array}{l}\text { Hasil Yang } \\
\text { diharapkan }\end{array}$ & Hasil \\
\hline Login & $\begin{array}{l}\text { User memasukkan } \\
\text { username dan password }\end{array}$ & $\begin{array}{l}\text { User masuk ke halaman } \\
\text { admin }\end{array}$ & Berhasil \\
\hline $\begin{array}{l}\text { Input Data Paket } \\
\text { Pengadaan }\end{array}$ & $\begin{array}{l}\text { Pilih menu paket, } \\
\text { masukkan data paket } \\
\text { sesuai form input, } \\
\text { tekan simpan }\end{array}$ & $\begin{array}{l}\text { Data paket pengadaan } \\
\text { bertambah }\end{array}$ & Berhasil \\
\hline $\begin{array}{l}\text { Ubah/Edit Data } \\
\text { Paket Pengadaan }\end{array}$ & $\begin{array}{l}\text { Pilih menu paket, cari } \\
\text { Salah satu paket pada } \\
\text { tabel data paket } \\
\text { pengadaan, klik icon } \\
\text { pensil/edit, ubah data, } \\
\text { tekan tombol update }\end{array}$ & $\begin{array}{l}\text { Data paket pengadaan } \\
\text { ter- updatel berubah }\end{array}$ & Berhasil \\
\hline $\begin{array}{l}\text { Hapus Data Paket } \\
\text { Pengadaan }\end{array}$ & $\begin{array}{l}\text { Pilih menu paket, cari } \\
\text { Salah satu paket pada } \\
\text { tabel data paket }\end{array}$ & $\begin{array}{l}\text { Data paket pengadaan } \\
\text { terhapus }\end{array}$ & Berhasil \\
\hline
\end{tabular}




\begin{tabular}{|c|c|c|c|}
\hline Test Case & $\begin{array}{c}\text { Prosedur yang } \\
\text { dijalankan }\end{array}$ & $\begin{array}{l}\text { Hasil Yang } \\
\text { diharapkan }\end{array}$ & Hasil \\
\hline & $\begin{array}{l}\text { pengadaan, klik icon } \\
\text { trash/hapus, muncul } \\
\text { notifikasi pilihan, tekan } \\
\text { hapus data }\end{array}$ & & \\
\hline $\begin{array}{l}\text { Cari Data Paket } \\
\text { Pengadaan }\end{array}$ & $\begin{array}{l}\text { Pilih menu paket, } \\
\text { masukkan keyword/kata } \\
\text { kunci pada kolom } \\
\text { pencarian }\end{array}$ & $\begin{array}{l}\text { Data paket pengadaan } \\
\text { yang dicari } \\
\text { ditampilkan/di temukan }\end{array}$ & Berhasil \\
\hline $\begin{array}{l}\text { Lihat Data Paket } \\
\text { Pengadaan }\end{array}$ & $\begin{array}{l}\text { Lihat Data Paket } \\
\text { Pengadaan Pilih menu } \\
\text { paket, klik pada nama } \\
\text { salah satu paket pada } \\
\text { tabel data paket } \\
\text { pengadaan }\end{array}$ & $\begin{array}{l}\text { Detail data paket } \\
\text { pengadaan ditampilkan }\end{array}$ & Berhasil \\
\hline $\begin{array}{l}\text { Cetak Summary/ } \\
\text { Laporan Data Paket } \\
\text { Pengadaan }\end{array}$ & $\begin{array}{l}\text { Pilih menu paket, klik } \\
\text { tombol "Cetak Paket" } \\
\text { pada halaman data paket }\end{array}$ & $\begin{array}{l}\text { Format cetak laporan } \\
\text { data paket pengadaan } \\
\text { ditampilkan pada } \\
\text { halaman baru }\end{array}$ & Berhasil \\
\hline Input Data Penyedia & $\begin{array}{l}\text { Pilih menu penyedia, } \\
\text { masukkan data } \\
\text { informasi penyedia } \\
\text { sesuai form input, tekan } \\
\text { tombol simpan }\end{array}$ & $\begin{array}{l}\text { Data penyedia } \\
\text { bertambah }\end{array}$ & Berhasil \\
\hline $\begin{array}{l}\text { Ubah/Edit Data } \\
\text { Penyedia }\end{array}$ & $\begin{array}{l}\text { Pilih menu penyedia, } \\
\text { cari salah satu } \\
\text { paket pada tabel data } \\
\text { penyedia, klik icon } \\
\text { pensil/edit, ubah data, } \\
\text { tekan tombol update }\end{array}$ & $\begin{array}{l}\text { Data penyedia ter- } \\
\text { updatel berubah }\end{array}$ & Berhasil \\
\hline $\begin{array}{l}\text { Hapus Data } \\
\text { Penyedia }\end{array}$ & $\begin{array}{l}\text { Pilih menu penyedia, } \\
\text { cari salah satu penyedia } \\
\text { pada tabel data } \\
\text { penyedia, klik icon } \\
\text { trash/hapus, muncul } \\
\text { notifikasi pilihan, tekan } \\
\text { hapus data }\end{array}$ & Data penyedia terhapus & Berhasil \\
\hline $\begin{array}{l}\text { Cari Data } \\
\text { Penyedia }\end{array}$ & $\begin{array}{l}\text { Pilih menu penyedia, } \\
\text { masukkan keyword/kata } \\
\text { kunci pada kolom } \\
\text { pencarian }\end{array}$ & $\begin{array}{l}\text { Data penyedia yang } \\
\text { dicari ditampilkan/di } \\
\text { temukan }\end{array}$ & Berhasil \\
\hline Lihat Data Penyedia & $\begin{array}{l}\text { Pilih menu penyedia, } \\
\text { klik pada nama salah } \\
\text { satu penyedia pada tabel } \\
\text { data penyedia }\end{array}$ & $\begin{array}{l}\text { Detail data penyedia } \\
\text { ditampilkan }\end{array}$ & Berhasil \\
\hline $\begin{array}{l}\text { Cetak Summary/ } \\
\text { Laporan Data } \\
\text { Penyedia }\end{array}$ & $\begin{array}{l}\text { Pilih menu penyedia, } \\
\text { klik tombol "Cetak } \\
\text { Penyedia" }\end{array}$ & $\begin{array}{l}\text { Format cetak laporan } \\
\text { data penyedia } \\
\text { ditampilkan pada } \\
\text { halaman baru }\end{array}$ & Berhasil \\
\hline
\end{tabular}

\section{SIMPULAN DAN SARAN}

Dari hasil penelitian yang dilakukan oleh penulis mulai tahapan analisis kebutuhan, perancangan desain dan implementasi serta ujicoba aplikasi SiMDA-PBJ yang telah dilakukan terdapat beberapa kesimpulan yang dapat dikemukakan diantaranya sebagai berikut 
a. Aplikasi sistem manajemen data pengadaan barang atau jasa (SiMDA-PBJ) berbasis web pada Pemerintah Kabupaten Malang ini dirancang sebagai sarana penunjang/ pelengkap dari sistem pengadaan secara elektronik yang dibuat oleh Lembaga Kebijakan Pengadaan Barang atau Jasa Pemerintah (LKPP) Republik Indonesia dalam hal penyajian data secara real-time terkait paket pekerjaan pengadaan barang atau jasa yang dilakukan dengan metode tender maupun seleksi pada Pemerintah Kabupaten Malang.

b. Aplikasi SiMDA-PBJ ini bersifat terbuka untuk umum dimana akan memudahkan pegunjung atau masyarakat apabila ingin mengetahui data informasi pengadaan barang atau jasa pemerintah pada Pemerintah Kabupaten Malang.

c. Aplikasi SiMDA-PBJ ini dibuat dengan tujuan memudahkan fleksibilitas dalam penginputan data, sehingga aparatur dapat melakukan pekerjaan kapan dan dimanapun selama terhubung dengan internet. Aplikasi SiMDA-PBJ juga digunakan sebagai pelaporan kepada pejabat eksekutif dalam hal ini Bupati Malang selaku kepala daerah sebagai bentuk peningkatan kinerja perangkat daerah Bagian Pengadaan Barang atau Jasa Sekretariat Daerah Kabupaten Malang. Data yang dilaporkan diantaranya adalah daftar paket pekerjaan pengadaan barang atau jasa, data penyedia barang atau jasa, efisiensi pagu anggaran dan harga perkiraan sendiri (hps) terhadap harga penawaran serta jumlah paket yang telah dimenangkan oleh masing - masing penyedia barang atau jasa.

Beberapa Saran yang dapat dipakai sebagai acuan guna penelitian lebih lanjut, sebagai berikut :

a. Perlu pengembangan lebih lanjut terhadap aplikasi SiMDA-PBJ seperti adanya penambahan fitur/modul tentang disposisi paket pekerjaan kepada kelompok kerja pemilihan, sehingga bisa didapatkan indikator persebaran paket pekerjaan pengadaan barang atau jasa dimana hal tersebut terhubung dengan besaran honorarium yang diterima untuk kegiatan pemilihan penyedia barang atau jasa.

b. Dibutuhkan sebuah server dan domain khusus jika aplikasi ini nantinya diimplementasikan pada perangkat daerah

c. yang bersangkutan agar nantinya dapat dipergunakan secara nyata.

d. Dengan status aplikasi yang telah memiliki domain dan server tersendiri, maka akan memudahkan aplikasi SiMDA-PBJ ini untuk di akses dimana saja dan kapan saja.

\section{DAFTAR PUSTAKA}

[1] Awaludin, Ahmad. 2016. Menyelami Framework Laravel. Jakarta: Gramedia..

[2] Bassil. 2012. System Development Life Cycle. Boston: Cengage Learning.

[3] Hakim. 2015. Belajar Laravel Untuk Pemula. Jakarta: Elexmedia Komputindo.

[4] Laudon, Kenneth C. 2012. Management Information Systems: Managing The Digital Firm, Twelfth Edition. New Jersey: Prentice Hall Inc..

[5] Shelly, B Shelly., Rosenblatt, Harry J. 2008. Systems Analysis and Design, Ninth Edition. Boston: Cengage Learning.

[6] Solichin. 2016. Belajar Permograman PHP 5, Javascript dan HTML. Jakarta: Gramedia.

[7] Stair, Ralph M., Reynolds, George W. 2015. Principles of Information Systems A Managerial Approach Ninth Edition. Boston: Cengage Learning.

[8] Supono., Putratama. 2016. Belajar Bahasa Pemrograman PHP (Hypertext Preprocessor). Jakarta: Andika.

[9] Sunyoto. 2017. Javascript Tingkat Dasar. Surabaya: Apollo.

[10] Tina, Marlinda, Devitra, Joni.2020. Analisis Dan Perancangan Sistem Informasi Layanan Pengadaan Barang Dan Jasa Berbasis Web Pada Polda Jambi. Jurnal Manajemen Sistem Informasi Vol.5, No.1. 